\title{
THE IMPACT OF ROAD TRAFFIC NOISE ON HOUSING PRICES - CASE STUDY IN POLAND
}

\author{
Kinga Szopińska \\ Faculty of Civil and Environmental Engineering and Architecture \\ UTP University of Science and Technology, Bydgoszcz, Poland \\ e-mail:k.szopinska@utp.edu.pl \\ Małgorzata Krajewska \\ Faculty of Civil and Environmental Engineering and Architecture \\ UTP University of Science and Technology, Bydgoszcz, Poland \\ e-mail:malgorzata.krajewska@utp.edu.pl

\section{Janusz Kwiecień} \\ Faculty of Civil and Environmental Engineering and Architecture \\ UTP University of Science and Technology, Bydgoszcz, Poland \\ e-mail:jkw@utp.edu.pl
}

\begin{abstract}
Noise as a form of environmental pollution negatively affects the attractiveness of residential areas. Its adverse effect is particularly noticeable in the vicinity of roads with high traffic volume. Along with the dynamic development of roads, the problem of the impact of traffic noise on the prices of residential real estate is now common. The purpose of this article was to determine the impact of road traffic noise from a busy route on residential property prices using strategic noise map (SNM) resources as a source of information on real estate. Housing estate was identified in the area of the Polish city of Bydgoszcz. Assuming that the prices of real estate reflect its characteristics, the article attempts to verify the following hypothesis: for residential premises located at Kujawska St., noise is a feature that reduces their price. SNM resources, statistical analyses and econometric modelling were used in the research. The studies show that housing prices vary with acoustic zones, but differences in prices in the areas surveyed are not statistically significant. In addition, the undertaken research has shown that SNM resources can be a source of information on real estate, especially in the context of environmental factors.
\end{abstract}

Key words: housing market, road traffic noise, strategic noise map, real estate value.

JEL Classification: Q51, Q53, R31

Citation: Szopińska, K., Krajewska, M., Kwiecień, J. (2020). The impact of road traffic noise on housing prices - case study in Poland. Real Estate Management and Valuation, 28(2), 21-36.

DOI: https://doi.org/10.1515/remav-2020-0013

\section{Introduction}

The location of a residential propert and, consequently, its surroundings, is one of the main determinants of the market value of residential real estate, a measure of which is its price. The placement of a residential building in the vicinity of a traffic route subjects it to a wide range of effects (Noga, Balawejder \& Nosek, 2018). The presence of such routes may increase organizational benefits 
related to accessing the real estate, but may also carry the risk of real estate value depreciation as a result of the emerging noise nuisance connected with traffic noise (Olbińska, 2015; Radziszewska \& Jaroszewicz, 2013). The impact of noise on housing prices is felt particularly in the vicinity of roads characterized by high traffic volume (Levkovich, et al., 2016). In Poland, these types of roads include those of national importance (indicated with the DK symbol). This problem is perceived by both road administrators and those involved in planning processes, as well as by local real estate market participants (e.g. owners of the surrounding premises). In this context, along with the dynamic development of roads and motorways, the problem of housing prices, as real estate that is sensitive to noise and thus possibly at risk of a decreased comfort of living, is becoming a pressing issue. The problem outlined above provides grounds for follow-up research on the impact of road traffic noise on the prices of living premises located in the area of busy transportation routes. In Poland, residential real estate, as goods enabling basic human needs (such as sleep, meal consumption, rest, family life, learning, housework, etc.) to be met, have been divided into the following categories: single-family homes as detached, semi-detached and terraced houses, tenement houses, and dwellings in multifamily buildings (including living premises as well as cooperative member's ownership right to residential premises). In Poland, over $60 \%$ of housing resources are located in multi-family buildings, consisting of residential units (flats); hence, as the dominant one, this housing market became the subject of the present research. The purpose of the article is to determine the impact of traffic noise from a busy transportation route on residential property prices using strategic noise map (SNM) resources as a source of real estate information. Assuming that real estate property prices reflect their characteristics, the following hypothesis has been formulated: for residential premises located at Kujawska St., noise is feature that reduces their price.

Housing estate in the Polish city of Bydgoszcz, dominated by multi-family residential buildings dating back to the 1980s, was selected for the purposes of the research. The selected housing estate is located near transportation route (national road), which constitute the southern exit road from Bydgoszcz. Two acoustic zones (NOISE ZONE and QUIET ZONE) were identified in the area of the examined road, and, subsequently, the housing market in the area under the influence of the abovementioned zones was assessed. The analysis was carried out on transaction prices completed in the years 2012-2016, derived from notarial acts contained in the real estate cadastre alongside data on road traffic noise contained in an immission map of the $\mathrm{L}_{\mathrm{DEN}}$ indicator of the strategic noise map (SNM) system of Bydgoszcz. The above acoustic data are the result of phase II of the SNM mapping system in Europe. Accordingly, under the European Commission's order, these data are current and valid for a period of five years, from 2012 to 2016 (END 2002). The research was carried out using the following test methods:

1) studies of literature and laws regarding the protection of the environment against road traffic noise,

2) studies of source materials, including information from land and building registers, strategic noise map (SNM) resources, and a base map of the study area,

3) an analysis of the transaction prices of dwellings,

4) complete study of transaction prices, including statistical test calculations and econometric modelling.

Moreover, the following computer software was used for quantitative and qualitative analyses: GeoMedia Professional (program for spatial analyses), CadnaA (program for noise analyses), Excel spreadsheet software, Statistica 13.1 computer software and a program for analyzing real estate transaction prices called Walor. Site inspections were used for the description of the properties.

\section{Literature review}

Since the mid-1960s, road traffic noise has been the biggest nuisance in highly industrialized urban space. According to research conducted by Szopińska (2017), and based on strategic noise map (SNM) data available on the Noise Observation and Information Service for Europe (NOISE) website, almost $16 \%$ of the population of the European Union in agglomerations exceeding 250,000 people is exposed to road traffic noise. The most favorable acoustic conditions (the smallest proportion of the population exposed to road traffic noise) were recorded in Italy, Estonia, France, Germany and Portugal. In Poland, traffic noise affects about $40 \%$ of the population. The same situation applies to large countries such as Slovakia, Ireland and Bulgaria. The above studies are also confirmed by the results of the 2014 EEA report (EEA 2002). Road traffic noise, which negatively affects the attractiveness of an area (King 
\& Murphy, 2016; Murphy \& Douglas, 2018), may reduce the functional and utility value of buildings. This applies in particular to buildings with a residential function, the main role of which is to ensure optimal living conditions around-the-clock. Residential real estate includes the actual land on which a real estate investment can be realized, real estate that has already been developed with a residential building, as well as residential units (also referred to as flats). The level of residential real estate prices is related to different levels of environmental variables, including road traffic noise, the values of which vary depending on the distance from the source (Blanco \& Flindell, 2011). Research conducted in the 1950s in the United States in, among others, Dallas, Houston and San Antonio, and later in the 70s-90s in Washington (Palmquist, 1979) or Texas (LEWIS et al. 1997), shows that the presence of a busy transportation route causes a statistically significant drop in the value of real estate located in a traffic noise zone (Levkovich, et al., 2016). A study conducted in Italy near one of the Neapolitan roads showed that the value of residential property fell by about $0.30 \%$ per decibel of road traffic noise in the daytime hours and by about $0.33 \%$ at night (Del Giudice, et al., 2017). According to research carried out by Wilhelmsson (2000) on a sample of 292 residential houses located in the Ängby district of Stockholm, the prices of residential houses situated next to noisy roads are $30 \%$ lower than of those in quiet locations. Similar results were obtained by Rich and Nielsen (2004), who examined residential real estate in Copenhagen, and by Brandt and Maennig (2011), who claim that quiet residential areas are more attractive for living than areas exposed to road traffic noise. Such exposure, as stated by Cellmer (2011), may pose a major problem in the process of real estate management in urban areas.

Research conducted in a number of Polish cities, i.e., in Olsztyn, Bydgoszcz and Szczecin, revealed a link between transaction prices and the level of road traffic noise. Szczepańska, Senetra and Wasilewicz (2014) analyzed the prices of housing in Olsztyn housing estates by conducting the interpolation of market price distribution using Shepard's method (inverse distance weighted), and then by division into three price categories and graphic juxtaposition with the acoustic map of Olsztyn. In their conclusions, the researchers found that higher prices were obtained for premises located deep within housing estates, and observed a decline in the market prices of those close to roads, though they did not specify the extent of traffic noise's impact on prices (Szczepańska, et al., 2015). Cellmer (2011) pointed to the usefulness of geostatistical methods in research assessing the influence of road traffic noise on the market value of residential real estate in Olsztyn, showing that road traffic noise has a significant impact on value, while the results of a simple regression analysis suggest that, in the assumed research area, individual prices fall by $16.53 \mathrm{PLN} / \mathrm{m}^{2} \mathrm{UA}$ with a noise level increase of $1 \mathrm{~dB}$. Krajewska and Szopińska (2012) examined the transaction prices of flats in one of the housing estates of Bydgoszcz by analyzing the average prices calculated for each zone, based on SNMs and accounting for "ceteris paribus" (with other conditions remaining the same) when selecting similar premises. The authors stated that, in the chosen research area of Bydgoszcz, buyers respond to the acoustic climate through the prices they are willing to pay for real estate, with lower market prices for flats located in areas with increased noise levels. Further research by the same authors showed that the level of road traffic noise is a value-influencing market factor (Szopińska \& Krajewska, 2016). This is also confirmed by Gnat and Bas (2014; 2017), who analyzed the prices of flats in selected housing estates in Szczecin. They examined whether there is a statistically significant relationship between the level of the LDEN indicator (long-term average noise level, determined for all days in a year) for road traffic noise and the average transaction prices of $1 \mathrm{~m}^{2}$ of UA (Usable Area) on the housing market. Results obtained in the years 2009 and 2010 indicated that the relationship between average prices and noise was statistically significant in all analyzed local markets. The strength of this relationship as demonstrated by the correlation ratios between the tested variables was moderate. The research was repeated in 2015-2016, with the results showing that the 6-year period which separated the carried out studies did not influence the relationship observed in the years 2009-2010. In all of the analyzed areas, there was a statistically significant link between the levels of the LDEN indicator for road traffic noise and real estate prices.

\section{Materials and Methods}

Carry out verification of the study hypothesis using two methods was made:

1) Method 1: of statistical tests for two averages on submarkets of similar flats,

2) Method 2: multiple regression, which is a linear model constructed using the classical linear regression model constructed using the ordinary least squares method. 
In order to carry out the study using Method 1, efforts were taken to select a data set on very similar real estate differing mainly in terms of the main feature, i.e. specific location, accounting for the level of noise. Unfortunately, in the present study, it was not possible to completely eliminate all the features differentiating the premises, particularly such individual aspects as the standard of finishing, the floor area and the floor a given flat is located on. However initially carried out distributions of the analyzed transaction prices were similar to that of a normal distribution, and according to Hozer (2001), such a distribution of prices should be expected when the variable is formed by a large number of factors, with no main factor - taking on such an assumption contributed to the selection of Test Method 1 (detailed description of the characteristics of the premises that create prices and differentiate the analyzed market is described in point 4.3.)

In order to verify the formulated study hypothesis, in addition to statistical calculations, econometric modelling was carried out applying the multiple linear regression model - Method 2. This method makes it possible to explain the impact of many explanatory variables on the explained variable (price). Multiple regression analysis can be conducted using the ordinary least squares (OLS) regression model and is conditioned by several assumptions: the model is linear (or can be brought to a linear form), explanatory variables (market features) are non-random values, co-linearity does not occur between the explanatory variables, the random factor is a random variable, the mathematical expectation of which is equal to zero, and variance is a constant, observations are independent, the random component is not correlated with explanatory variables, the number of explanatory variables is lower than the number of observations, there are no interdependencies between random components of individual equations of the model (Anselin \& Rey, 1991; Aiyin \& Yanmei, 2018; Wadud, 2013).

To perform statistical calculations and econometric modeling, it was necessary to prepare input data. In order to obtain two submarkets differing significantly only in terms of one feature, i.e. road traffic noise, the immission road traffic noise map of the $\mathrm{L}_{\mathrm{DWN}}$ indicator belonging to the SNM system of the analyzed area proved substantively necessary, as thanks to the creation algorithm it eliminates many factors differentiating city space (e.g., land relief and land development, the presence of different forms of noise protection including green belts, the distance of the building from the noise source, or the type of land) which affect the selection of the submarket. In addition, due to the timeliness of the source, confirmed in END (END 2002), the stability of parameters affecting the level of noise propagation in the period from 2012 to 2016 was assumed (phase II of the SNM mapping system in Europe). According to the END provision, this map is being carried out in phases. The first phase was completed in 2007, and concerned the compilation of noise maps for agglomerations of over 250,000 inhabitants and for main roads with over 6 million journeys per annum. The second phase, which was completed in 2012, included all agglomerations of over 100,000 inhabitants and main roads with more than 3 million journeys a year. SNM phase II data illustrate the acoustic situation for the period from early 2012 to the end of 2016. Works on the following mapping phase in all EU countries (phase III) was completed near the end of 2017. The SNM system consists of many digital noise maps, presenting a variety of problems connected with noise policy.

In the area of a city, the negative impact of noise pertains to noise sensitive objects. These include areas for which the legislator has defined formal requirements in the form of acceptable noise levels. The limiting values are set out within the national legislations of EU member states. There are no common regulations in this regard. Each country defines a sensitive area in a different way, as it introduces different threshold values and has different means of implementing noise policy objectives, the general principles of which are defined in Directive 2002/49/EC of the European Parliament and of the Council of 25 June 2002, relating to the assessment and management of environmental noiseOfficial Journal of the European Communities L 189 of 18 July 2012-known as the Environmental Noise Directive (END) (END 2002). In most countries, areas intended for residential development, as well as hospitals and premises of medical care centers, are under noise protection. In some countries, for example in Belgium, Germany or the United States, the permissible sound level values are determined separately for existing and planned sources. In Poland, included in areas of noise sensitivity are those for which limiting values for two groups of noise indicators (short-term indicators and long-term indicators) have been set out. Short-term indicators were calculated with respect to one day: $\mathrm{L}_{\mathrm{AeqD}}$, an equivalent sound level $(\mathrm{dB})$ for daytime (from 6 am to $10 \mathrm{pm}$ ) and $\mathrm{L}_{\mathrm{AeqN}}$, an equivalent sound level (dB) for night time (from $10 \mathrm{pm}$ to $6 \mathrm{am}$ ) (ACT of 2001...). Long-term indicators described in SNMs, including the average long-term sound level $\left(\mathrm{L}_{\mathrm{DEN}}\right)(\mathrm{dB})$ determined for all days in a year, as 
well as the average long-term sound level $\left(\mathrm{L}_{\mathrm{N}}\right)(\mathrm{dB})$ indicated for all nights in a year (from $10 \mathrm{pm}$ to 6 am) (END 2002).The limiting level depends on the analyzed noise indicator, source of emission and type of noise sensitive area. Permissible noise levels for long-term indicators in Poland have been set

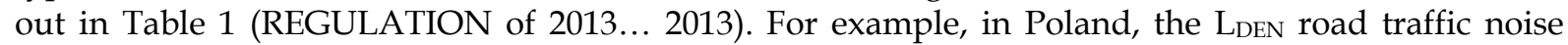
indicator presented in the SNM system for multifamily housing should not exceed 68dB. In the surroundings of real estate, the sources of environmental noise are spatial objects that lie in areas of noise nuisance, including traffic routes that generate noise from road, tram or rail traffic, production areas and airports.

With such assumptions described, the research was conducted in the following stages:

1) selection of research areas located in the area of a busy transportation route,

2) designation of two acoustic zones: NOISE and QUIET, resulting from the analyses of immission maps of the $\mathrm{L}_{\mathrm{DEN}}$ road traffic noise indicator presented on the SNM (Phase II of the SNM mapping in Europe) and the Polish legislation on acceptable levels of road traffic noise in the environment,

3) selection of the type of analyzed real estate market and research period of price analysis with the selection of data (the assumed period corresponded to Phase II of SNM mapping in Europe),

4) grouping transaction prices of residential premises along with their aggregation and allocation to two submarkets corresponding to two acoustic zones,

5) carrying out statistical analyses for designated submarkets (Method 1),

6) carrying out econometric modelling (Method 2),

7) drawing conclusions from the analysis.

Table 1

The permissible noise levels for long-term indicators in Poland

\begin{tabular}{|c|c|c|c|c|}
\hline \multirow{3}{*}{ Type of area } & \multicolumn{4}{|c|}{ Permissible noise level $\mathrm{dB}(\mathrm{A})$} \\
\hline & \multicolumn{2}{|c|}{$\begin{array}{l}\text { Roads or } \\
\text { railways }\end{array}$} & \multicolumn{2}{|c|}{$\begin{array}{c}\text { Other sources of } \\
\text { noise }\end{array}$} \\
\hline & $\mathrm{L}_{\mathrm{DEN}}$ & $\mathrm{L}_{\mathrm{N}}$ & $\mathrm{L}_{\mathrm{DEN}}$ & $\mathrm{L}_{\mathrm{N}}$ \\
\hline $\begin{array}{l}\text { The protection zone " } \mathrm{A} \text { " of health spas, hospital premises } \\
\text { outside of the city }\end{array}$ & 50 & 45 & 45 & 40 \\
\hline $\begin{array}{l}\text { Areas of single-family housing development, nursing homes, } \\
\text { hospitals in cities and built-up areas connected with } \\
\text { permanent or temporary stay of people }\end{array}$ & 64 & 59 & 50 & 40 \\
\hline $\begin{array}{l}\text { The area of multi-family residential development and multi- } \\
\text { apartment residential buildings, the farmstead building areas, } \\
\text { recreational and leisure areas, residential and service areas }\end{array}$ & 68 & 59 & 55 & 45 \\
\hline Areas in the city centers of cities with over 100,000 inhabitants & 70 & 65 & 55 & 45 \\
\hline
\end{tabular}

Source: REGULATION of 2013... (2013).

\section{Results and discussion}

\subsection{Characteristics of the research area}

The research was conducted in the Polish city of Bydgoszcz, which is one of the largest settlement centers in the country, located in its northern part. A study area was designated for the research, constituting fragments of multi-functional urban space with compact spatial structures. This is an area with a predominance of multi-family residential developments constructed using prefabricated technology built in the 1980s (also of multi-family residential developments, constructed using traditional technology), with an area of $0.37 \mathrm{~km}^{2}$, is located in the southern part of the city alongside national road DK25 - ul. Kujawska (hereinafter referred to as Kujawska St.), a main access road, and the exit road towards Wroclaw. It is part of the Wyżyny housing estate (cadastral districts: 495, 497, 499 and 492), which is situated approximately $1.5 \mathrm{~km}$ away from the city center (Figure 1.) Additionally, multi-family housing developments from the 1930s and basic service developments also appear in the area. 


\section{S sciendo}

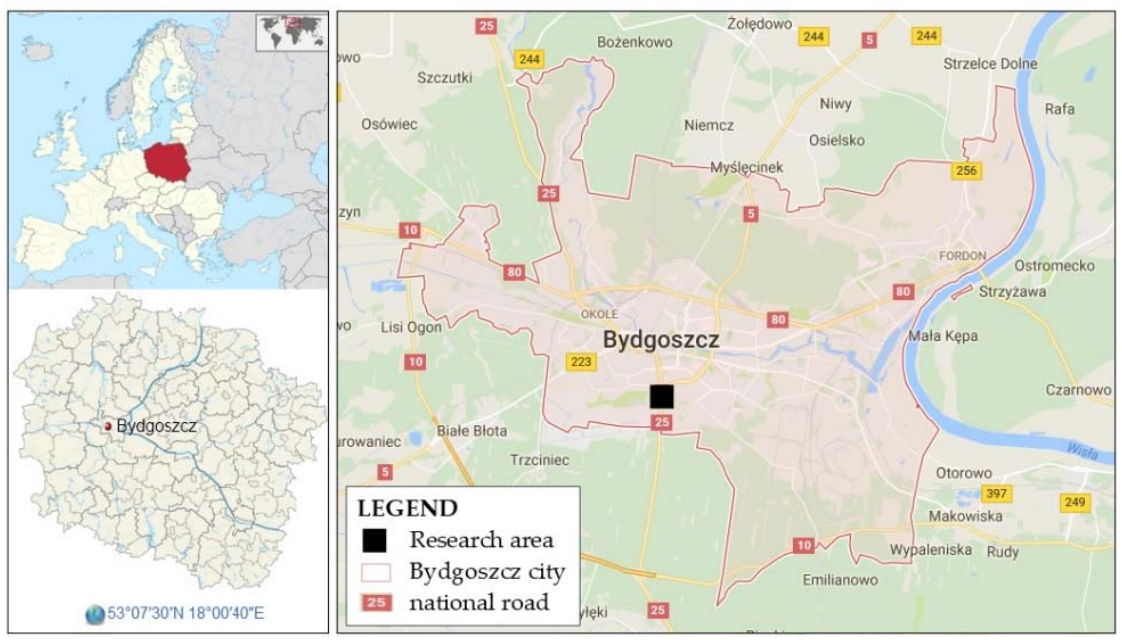

Fig. 1. Study site in the context of Bydgoszcz. Source: own study.

\subsection{Determination of the NOISE and QUIET zones based on the strategic noise map}

This is the most extensive and detailed phase of the research. The resources of the strategic noise map were used for the analysis of the real estate market as well as indicating two acoustic zones, i.e. NOISE and QUIET. SNM data of the city of Bydgoszcz, presented on a road traffic noise immission map of the $\mathrm{L}_{\mathrm{DEN}}$ indicator and showing the range of noise impact in the second phase of mapping, was used for purposes of the present work. This data is available on the web portal: http://mapy.bydgoszcz.pl/ (SNM 2017). Based on the SNM resources, the relationship between the different forms and means of development was explored by dividing objects into three groups: objects of noise sensitivity (Group 1 ), objects of noise nuisance (Group 2) and objects neutral to noise (Group 3). The subject of the research in the present work is road traffic noise, thus, the existing road sections were included among the objects of noise nuisance. The remaining objects were classified as noise neutral (incl. civil structures which were not classified in Group 2, woodlands, embankments, areas of technical infrastructure).

Once the objects were defined in space, places at potential risk of noise resulting from the impact of excessive road traffic noise on noise sensitive objects were identified. Because the presented research deals with determining the impact of a busy traffic route on the prices of residential units, the communication structure was divided into:

1) main sources (roads generating noise nuisance caused by exceeding the permissible level of road traffic noise in the area of noise sensitive objects),

2) auxiliary sources (roads with traffic not exceeding the permissible level of road traffic noise in the area of noise sensitive objects).

In the case of the emergence of several roads constituting a noise nuisance, only one of them was selected for further analysis, while the others were considered as sources generating so-called "cross nuisance". Further analyses also excluded noise sensitive objects that were under the influence of cross sources. Such selection required more in-depth identification of road traffic noise sources, covering all component routes of the communication system. With this end in view, the road infrastructure of the selected areas was divided into homogenous acoustic sections, the noise level parameters of which are more or less constant. For each section, information about its characteristics was obtained (i.e. the category of road, the type of road, the number of lanes and direction of traffic, the type and condition of the pavement), the organization of road traffic (e.g., the maximum permissible speed of vehicles and the presence of traffic lights) and traffic data by type (e.g. the number of vehicles per hour, the share of heavy vehicles). For such an extensive analysis, the GIS database, Intergraph's GeoMedia Professional software for spatial analysis, and Data Kustik's CadnaA acoustic analysis software were used, making it possible to precisely identify the main, auxiliary and cross-sources.

Then, two acoustic zones were designated for only the main source: 
1) the first acoustic zone, referred to as the NOISE ZONE, is an area of noise nuisance created by the impact of road traffic noise exceeding the permissible value for the analyzed noise sensitive objects and the analyzed long-term noise indicator,

2) the second acoustic zone, referred to as the QUIET ZONE, is an area outside the zone of noise nuisance, created by the impact range of road traffic noise not exceeding the permissible values for the analyzed noise sensitive objects and the analyzed long-term noise indicator.

Moreover it was assumed that a multi-family building located in the NOISE ZONE is a civil structure with at least one entire façade (defined as an external partition with openings), exposed to excessive road traffic noise (in this work it a value of over $68 \mathrm{~dB}$ - see Table 1). In addition, due to the subject matter of the research, i.e. residential units, the border of the NOISE ZONE was determined only on the grounds of the footprint of the building which the residential unit is a part of. However, in the case of land property developed with a single-family house, the NOISE ZONE was determined by the boundaries of the lot which the noise sensitive object is located on.

Only noise generated by existing traffic routes was identified in the research area. The spatial layout of these routes is shown in Figure 2. When analyzing the road layout of the study area from the beginning of 2012 to the end of 2016, no transportation innovations consisting in the extension of the existing road system and the construction of new sections of roads were confirmed. Thus, SNM resources (the second phase of mapping) were used for further studies. Transportation in the analyzed area takes place on asphalt roads, with a good condition of the road surface. Most of these are municipal roads: bidirectional and single-lane roads, with a permissible speed for wheeled vehicles of $50 \mathrm{~km} / \mathrm{h}$. Following site inspection, no noise protection in the form of noise barriers or green belts was noted. The detailed characteristics of the homogeneous acoustic sections at the time of SNM generation have been presented in Table 2.

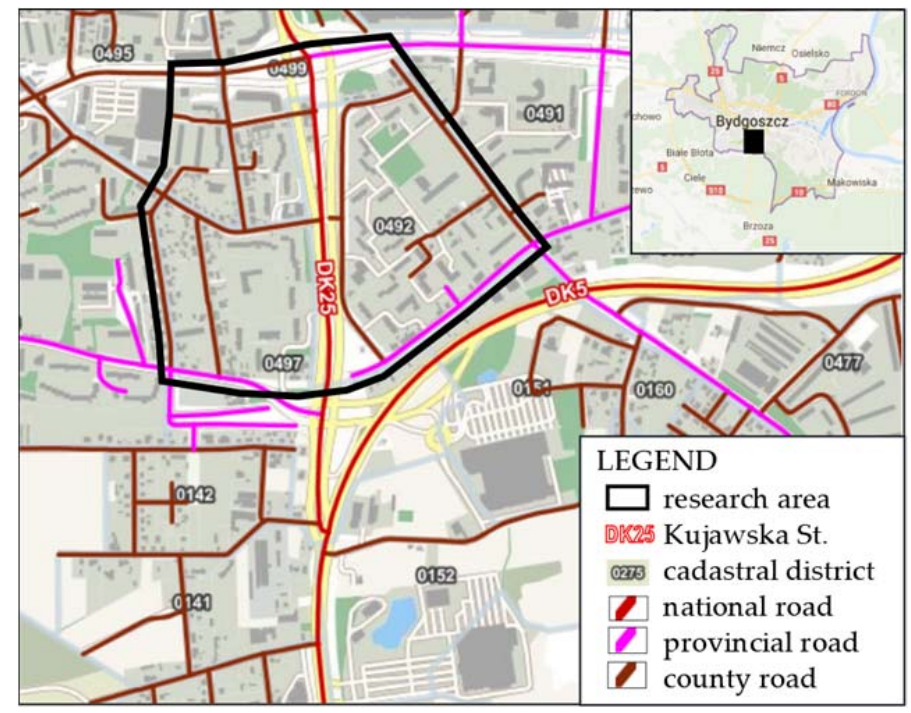

Fig. 2. Road layout for research area. Source: own study.

The rationale for identifying the main source were roads of national importance which constitute exit roads from the city, with a traffic volume of over 1,000 vehicles per hour (see Table 2 - row marked in red), including Kujawska St., national road DK25, located in the central part of the housing estate, bidirectional, with four lanes separated by a green belt. Moreover, road traffic noise sources generating cross-nuisance in the area of residential buildings located at the first frontage alignment from the road were defined in the research area. These are roads with traffic volume exceeding 1,000 vehicles per hour (see Table 2 - row marked in grey).

By analyzing noise data found on a road traffic noise imission map of the LDEN indicator of the SNM system for the city of Bydgoszcz (SNM 2017), acoustic zones were identified for main noise source. Noise generated by Kujawska St. contributes to the emergence of noise nuisance in adjacent areas of almost $0.10 \mathrm{~km}^{2}$ (NOISE ZONE). The QUIET ZONE represents the remaining area of $0.28 \mathrm{~km}^{2}$, which accounts for two thirds of the total research area. All multi-family buildings located in the first frontage alignment from main source are affected by noise nuisance (Figure 3). 
Table 2

Characteristics of road traffic noise sources

\begin{tabular}{|c|c|c|c|c|c|}
\hline Name of street & Road category & $\begin{array}{c}\text { Number of passenger } \\
\text { vehicles }^{1} \\
\text { [vehicles } / \mathrm{h}]\end{array}$ & $\begin{array}{c}\text { Share of heavy } \\
\text { goods } \\
\text { vehicles }{ }^{2} \\
{[\%]}\end{array}$ & $\begin{array}{l}\text { Speed } \\
\text { limit } \\
{[\mathrm{km} / \mathrm{h}]}\end{array}$ & $\begin{array}{c}\text { Traffic } \\
\text { lights } \\
\text { [Yes/No] }\end{array}$ \\
\hline Kujawska & national & 1171 & 7.0 & 50 & Yes \\
\hline Wojska Polskiego & provincial & 1630 & 3.9 & 50 & Yes \\
\hline Solskiego & county & 1579 & 3.7 & 50 & Yes \\
\hline Brzozowa & provincial & 1182 & 6.0 & 50 & Yes \\
\hline Ujejskiego & provincial & 141 & 0.0 & 50 & No \\
\hline Beskidzka & county & 141 & 0.0 & 30 & No \\
\hline Tucholska & county & 141 & 0.0 & 30 & No \\
\hline Karpacka & county & 141 & 0.0 & 30 & No \\
\hline Lwowska & county & 53 & 0.0 & 50 & No \\
\hline Chołoniewskiego & county & 55 & 0.0 & 50 & No \\
\hline Konopnickiej & county & 290 & 1.4 & 50 & No \\
\hline Orzeszkowej & county & 53 & 0.0 & 30 & No \\
\hline Jesionowa & provincial & 36 & 0.0 & 30 & No \\
\hline
\end{tabular}

Source: own study.

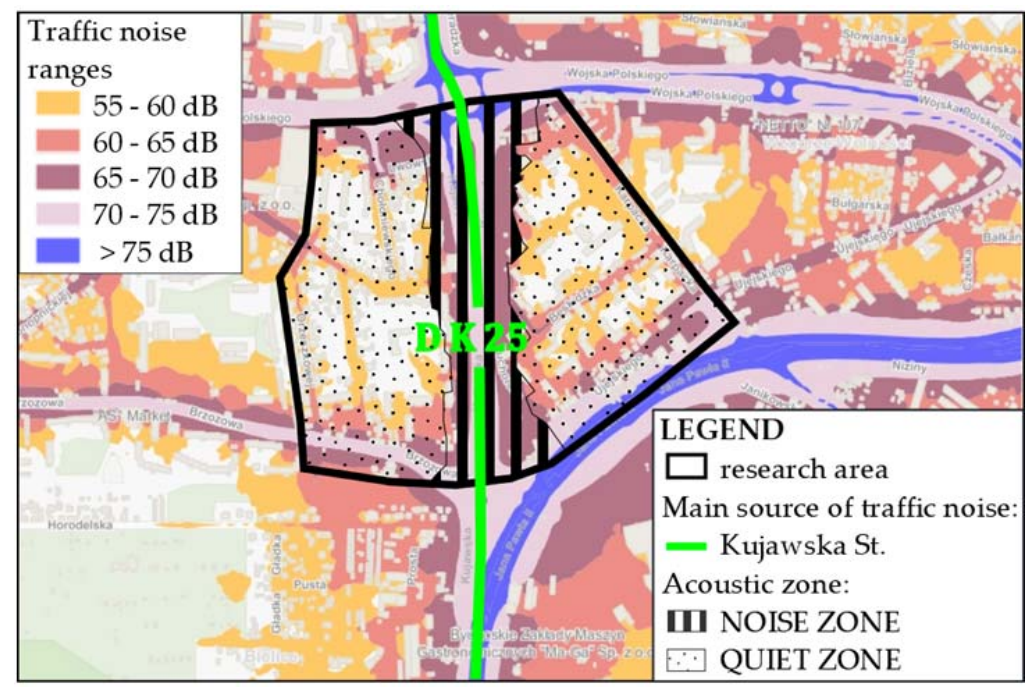

Fig. 3. The spatial range of acoustic zones with respect to the main source on the ambient concentration road traffic noise imission map of the $\mathrm{L}_{\mathrm{DEN}}$ indicator. Source: own study.

\subsection{Identification of the real estate market accounting for acoustic zones}

The study attempted to select a set of data on very similar properties and divide them into two NOISE and QUIET zones. Similar features included the choice of housing estate, age and architecture of building and a similar location of buildings (i.e. buildings located outside the area of "cross nuisance" sources), thus eliminating such features as:

\footnotetext{
1 The number of passenger vehicles was determined by the manual method, based on the sampling method. Direct measurements of traffic were carried out five times a day for 15 minutes, in the following time intervals: time of day (morning and afternoon traffic rush hour, and hour outside traffic peak), evening time and night time. Then, the results obtained were averaged. Measurements were made on defined acoustically-homogenous road sections for which the parameters determining the noise level are approximately constant. During the sample, the type structure of traffic divided into light and heavy vehicles (over $3.5 \mathrm{t}$ ) was also determined (SZOPIŃSKA 2018).

2 This is the ratio of heavy goods vehicles $>3.5$ tons to the number of actual vehicles. The term "actual vehicles" means all motor vehicles.
} 
1) general location in the city of Bydgoszcz, including transport structure appropriate for the given district and access to the city center,

2) technical infrastructure,

3) social infrastructure and access to services,

4) building management method and operating costs related to $1 \mathrm{~m}^{2}$ (including heating method and cost),

5) building architecture and spatial order,

6) fashion,

7) functional layout of apartments (including size of rooms, type of balconies, size of windows and lighting of rooms),

8) development of the estate.

Unfortunately, it was not possible to completely eliminate all the features that differentiate the premises, especially the individual ones, such as:

1) usable area of apartment (the study assumed the area from $31.31 \mathrm{~m}^{2}$ to $84.70 \mathrm{~m}^{2}$ ),

2) type of building - low, high,

3) construction technology - traditional, prefabricated,

4) floor - division into vertical zones,

5) technical condition of the apartment is narrowed to apartment in average technical conditions and for renovation (the differentiation was adopted on the basis of information contained in notarial deeds),

6) detailed location, which is the feature of the real estate accounting for the noise level of traffic routes.

These features were introduced into the regression model - Method 2. Transaction prices of purchase/sales transactions of flats derived from notarial deeds contained in the real estate cadaster were used in the research in comparison with data from the National Geodetic and Cartographic Resource. This is historical market evidence obtained by the method of individual data collection. The price survey period corresponded to the current SNM mapping phase in Poland (phase II: from the beginning of January 2012 to the end of December 2016).

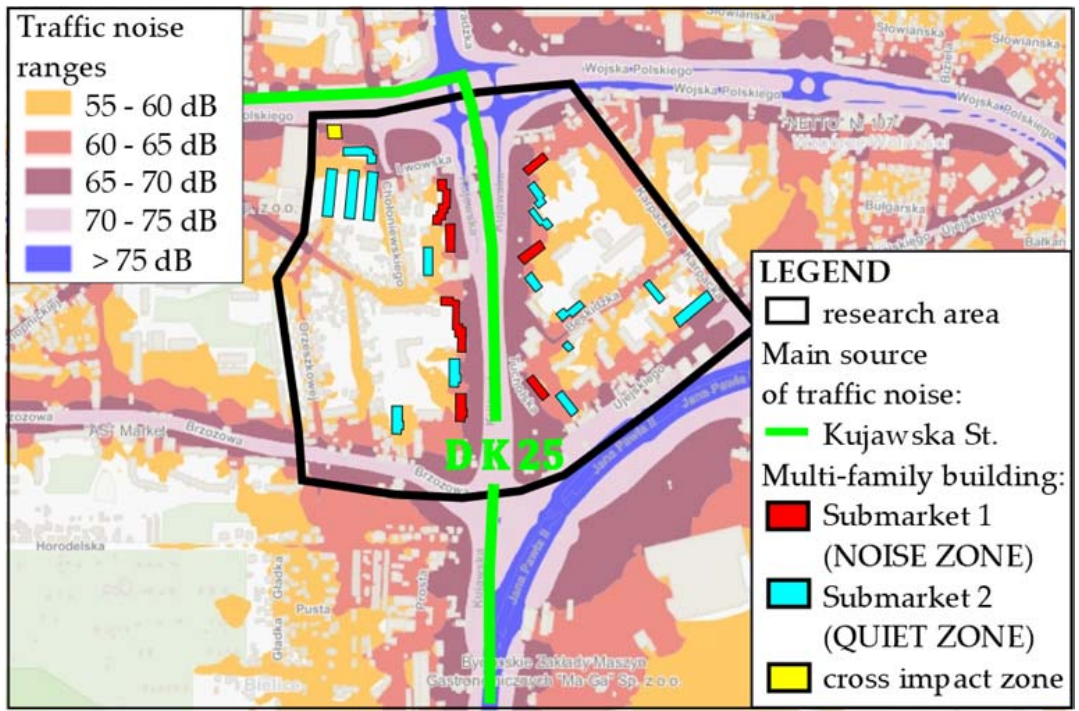

Fig. 4. Location of buildings with premises accepted for analyses. Source: own study.

For the defined type, market area and price survey period, a total of 139 transactions of residential units were aggregated, of which 37 were located in multi-family buildings. Transactions involving buildings which were erected after 2000 and tenement houses built in the 1930s were rejected for further analyses, as it was acknowledged that these transactions concerned real estate characterized by distinct technical conditions. Furthermore, transactions involving buildings subject to cross nuisance resulting from the impact of noise derived from cross-sources were eliminated. Thus, further analyses included 90 transactions of residential units located in 22 multi-family buildings (Table 3). The location of the buildings at different distances from main source resulted in the selection of two 
submarkets, the range of which coincides with the respective acoustic zones of: NOISE ZONE and QUIET ZONE (Figure 4).

Table 3

Identification of the residential real estate market with regard to acoustic zones

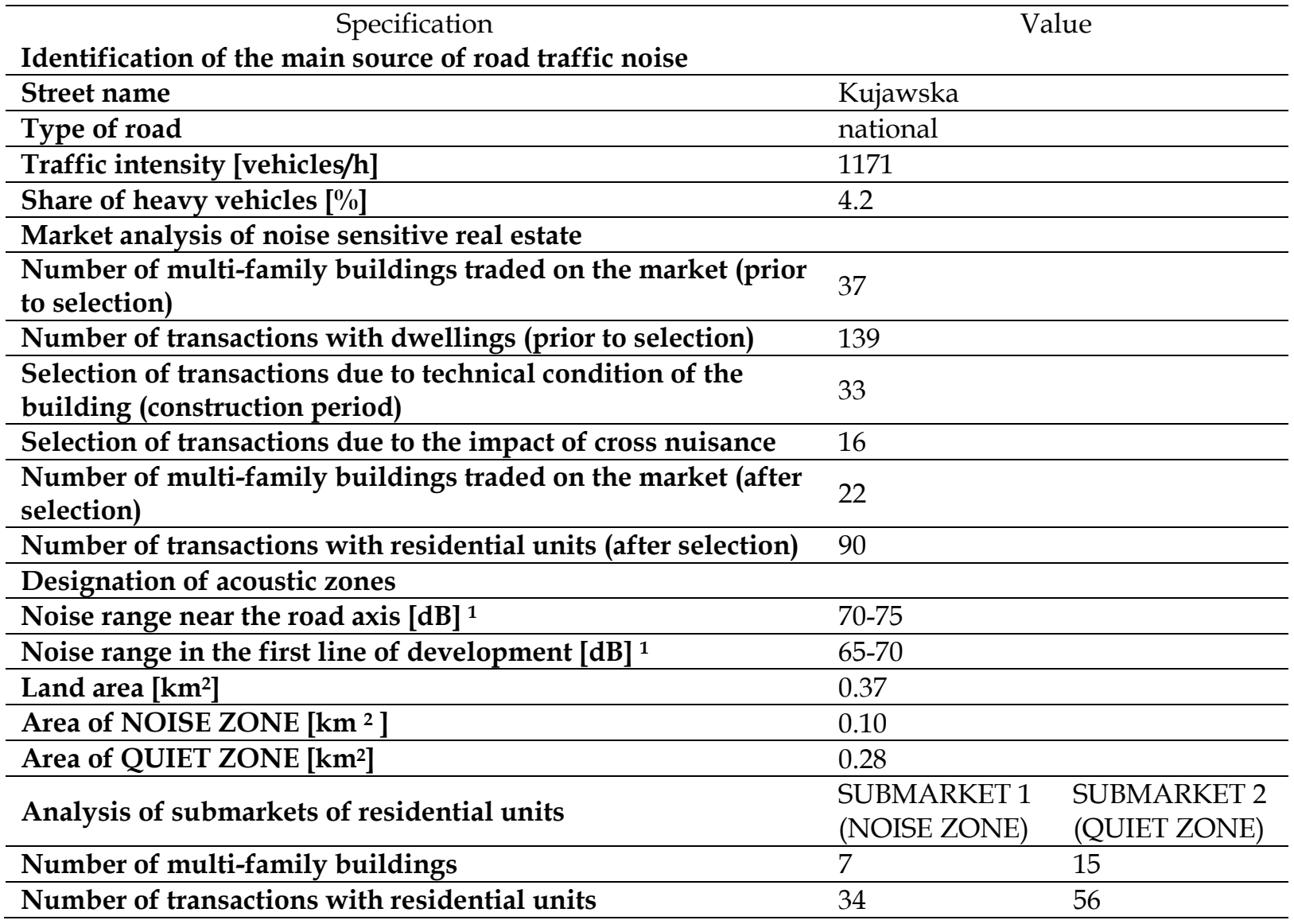

${ }^{1}$ Based on the road traffic noise immission map of the $L_{D E N}$ indicator for Bydgoszcz.

Source: own study.

\subsection{Analysis of transaction prices of residential units - Method 1}

Studying the trend for the analysed premises showed that the passage of time had little effect on the price change. From a statistical point of view, the directional assessment of the linear trend function was statistically insignificant, hence showing no effect of time on price volatility. This made it possible not to make corrections connected with changes in the level of prices resulting from the passage of time and to compare the analyzed prices with the noise level presented on the SNM. Basic statistical measures have been presented in Table 4 . On this basis, it can be stated that the average price in the period 2012-12016 in the NOISE ZONE is lower than that appearing in the QUIET ZONE.

Table 4

Cross-sections of transaction price $\left[\mathrm{PLN} / \mathrm{m}^{2} \mathrm{UA}\right]$ descriptive statistics for acoustic zones (period 20122016)

\begin{tabular}{lcccccc}
\hline \multirow{2}{*}{ Acoustic zone } & \multicolumn{6}{c}{ Statistical measures } \\
\cline { 2 - 7 } & $\begin{array}{c}\text { Average } \\
\text { price }\end{array}$ & Count & $\begin{array}{c}\text { Standard } \\
\text { deviation }\end{array}$ & $\begin{array}{c}\text { Minimum } \\
\text { price }\end{array}$ & $\begin{array}{c}\text { Maximum } \\
\text { price }\end{array}$ & Median \\
\hline NOISE ZONE & 3431.56 & 34 & 474.669 & 2488.59 & 4245.28 & 3270.115 \\
\hline QUIET ZONE & 3497.00 & 56 & 497.309 & 2045.31 & 4793.39 & 3492.595 \\
\hline
\end{tabular}

Source: own study. 
Statistical tests were performed to verify if the road traffic noise level as a market feature influences the difference between prices of real estate located in the two acoustic zones. First, by using the Shapiro-Wilk test, it was found that prices had a normal distribution pattern from year to year (these results have been presented in Table 5) and then verified whether the groups had constant variances (F-test - test statistics for variance homogeneity in groups). Consequently, to test the significance of price differences between dwellings in the two acoustic zones, the t-test of significance for two means was used (Table 6). The following hypotheses were assumed: H0: $\mu 1=\mu 2$ (average prices in both acoustic zones are equal; samples come from one population), H1: $\mu 1 \neq \mu 1$ (average prices in both acoustic zones are not equal; samples come from different populations). The t-test and F-test results include test probability values $\mathrm{p}$ ( $\mathrm{p}$-value) and the confidence intervals for each variable calculated at the level of $95 \%$.

As shown in Table 6 the test score is not significant at $p<0.05$, which confirms the null hypothesis of price $\left[\mathrm{PLN} / \mathrm{m}^{2} \mathrm{UA}\right]$ equality in both zones. Therefore it was found that the prices of dwellings in the analyzed areas within the NOISE ZONE are not significantly different from the prices in the QUIET ZONE. It is worth highlighting here that, in these cases, the lack of a relationship may also result from incomplete information regarding the features of the analyzed residential premises. When assessing attributes of premises, there may be difficulties due to the fact that, in Poland, the building of the cadastral system is in progress and there is no precise description of the subject of the transaction, e.g. the standard of finishing and functional layout of the premises, the technical condition of the building, or floors the premises are located on, may arise in the valuation. Gaps in the completeness of data in Poland are indicated by Racka (2017), who emphasizes that as many as $80 \%$ of the sources subjected to analysis contain incomplete information. It is also necessary to remember that transactions are historical proof of an event that took place $x$ months earlier, which in turn makes it more difficult to acquire reliable data on the day of the valuation.

Table 5

Shapiro-Wilk test for defined acoustic zones

\begin{tabular}{lcllrl}
\hline Year & NOISE ZONE & $\begin{array}{c}\text { Normal distribution } \\
{[\text { Yes } / \text { No] }}\end{array}$ & QUIET ZONE & $\begin{array}{c}\text { Normal distribution } \\
{[\text { Yes } / \text { No] }}\end{array}$ \\
\hline $\mathbf{2 0 1 2}$ & $W=.96329, p=.83070$ & Yes & $W=.92899, p=.36954$ & Yes \\
\hline $\mathbf{2 0 1 3}$ & $W=.82026, p=.06459$ & Yes & $W=.95415, p=.73558$ & Yes \\
\hline $\mathbf{2 0 1 4}$ & $W=.96438, p=.83443$ & Yes & $W=.92355, p=.42243$ & Yes \\
\hline $\mathbf{2 0 1 5}$ & $W=.86011, p=.18956$ & Yes & $W=.97704, p=.94527$ & Yes \\
\hline $\mathbf{2 0 1 6}$ & $W=.92811, p=.56561$ & Yes & $W=.89827, p=.17603$ & Yes \\
\hline Total & $W=.94132, p=.06749$ & Yes & $W=.98264, p=.59592$ & Yes \\
\hline
\end{tabular}

Source: own study.

Table 6

Significance test for two means for the defined acoustic zones (period 2012-2016)

\begin{tabular}{|c|c|c|c|c|c|c|c|}
\hline NOISE ZONE & QUIET ZONE & & & & & Decrease in & Increase in \\
\hline Average price & Average price & t-statistic & $\mathrm{p}$-value & F-statistic & $\mathrm{p}$-value & $\begin{array}{l}\text { prices in } \\
\text { NOISE } \\
\text { ZONE [\%] }\end{array}$ & $\begin{array}{c}\text { prices in } \\
\text { NOISE } \\
\text { ZONE [\%] }\end{array}$ \\
\hline 3431.56 & 3497.00 & -0.615662 & 0.539707 & 1.097668 & 0.786949 & 1.872 & - \\
\hline
\end{tabular}

Source: own study.

\subsection{Analysis of transaction prices of residential units - Method 2}

Multiple regression analysis was carried out using the ordinary least squares (OLS) regression model. First analyzed was the correlation between prices of flats and their features. In order to assess the correlations of quantitative features, Pearson's correlation coefficient was used, with the test of independence $\chi^{2}$ and adjusted contingency coefficient used for qualitative features. Further analysis 
accounted for the attributes of flats which were not strongly correlated with each other, presented in detail in Table 7.

Table 7

Qualitative and quantitative variables used in the regression model for flats

\begin{tabular}{|c|c|c|}
\hline Variable & Symbol & Description \\
\hline Price & Price & Price of flat $\left[\mathrm{PLN} / \mathrm{m}^{2} \mathrm{UA}\right]$ \\
\hline $\begin{array}{l}\text { Area of } \\
\text { apartment }\end{array}$ & Area & Usable area of apartment $\left[\mathrm{m}^{2}\right]$ \\
\hline $\begin{array}{l}\text { Type of } \\
\text { building }\end{array}$ & $\begin{array}{l}\text { Low }-1 \text { (building of up to } 4 \text { storeys) } \\
\text { High }-0 \text { (building of more than } 4 \text { storeys) }\end{array}$ & $\begin{array}{l}\text { A dummy variable. If the apartment is } \\
\text { located on the } 4^{\text {th }} \text { floor of a building, it } \\
\text { takes the value of } 1 \text {; otherwise it takes } 0\end{array}$ \\
\hline $\begin{array}{l}\text { Construction } \\
\text { technology }\end{array}$ & $\begin{array}{l}\text { Traditional - } 1 \text { (building constructed using } \\
\text { traditional technology) } \\
\text { Prefabricated - } 0 \text { (building constructed } \\
\text { using prefabricated technology) }\end{array}$ & $\begin{array}{l}\text { A dummy variable. If the apartment is } \\
\text { located in a building constructed using } \\
\text { traditional technology, it takes the value } \\
\text { of } 1 \text {; otherwise it takes } 0\end{array}$ \\
\hline Floor & 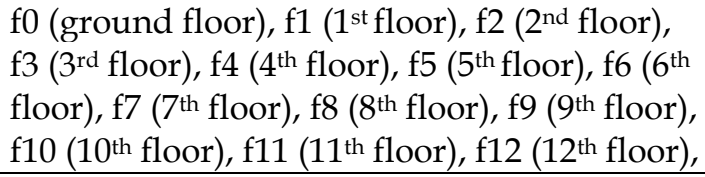 & $\begin{array}{l}13 \text { dummy variables. If the apartment is } \\
\text { located on a given floor, it takes the } \\
\text { value of } 1 \text {; otherwise it takes } 0\end{array}$ \\
\hline $\begin{array}{l}\text { Technical } \\
\text { condition of } \\
\text { apartment }\end{array}$ & $\begin{array}{l}\text { Average - } 1 \text { (apartment in average technical } \\
\text { conditions) } \\
\text { Renovation - } 0 \text { (apartment intended for } \\
\text { overhaul) }\end{array}$ & $\begin{array}{l}\text { A dummy variable. If the apartment is } \\
\text { in good technical condition, it takes the } \\
\text { value of } 1 \text {; otherwise it takes } 0\end{array}$ \\
\hline
\end{tabular}

QUIET ZONE - 1 (if building in which the apartment is located is exposed to road

Acoustic traffic noise of under $68 \mathrm{~dB}$ )

zone

NOISE ZONE - 0 (if the building in which the apartment is located is exposed to traffic A dummy variable. If the apartment is located in a QUIET ZONE, it takes the value of 1 ; otherwise it takes 0 noise of over $68 \mathrm{~dB}$ )

\section{Source: own study.}

Next, explanatory variables of low internal diversity (variation coefficient $\mathrm{V} \leq 0.10$ ), as well as those which were statistically not significantly correlated with the explanatory variable (construction technology, technical condition of apartment, location on floor above the $1^{\text {st }}$ ) were eliminated from the set of attributes. For the analyzed area, a model of time series was constructed, showing the influence of explanatory variables on the price of an apartment in a given area at a given time. The dependant variable in the models constructed below is the price per square meter $\left[\mathrm{PLN} / \mathrm{m}^{2} \mathrm{UA}\right]$ of a flat. The obtained regression coefficients can be interpreted as the influence of individual variables on the changes in unit prices: how much, on average, the unit price will change (increase or decrease) in the case when the independent variable which the given coefficient refers to increases by one unit. The results of regression have been presented in Table 8 .

Table 8

Multiple regression

Summary of dorsal regressions for dependent variables: Unit price $\mathrm{I}=0.10000 ; \mathrm{R}=0.37523840 ; \mathrm{R}$-squared $=0.14080385$;

Variable Adjusted R-squared $=0.08966123 ; \mathrm{F}(5.84)=2.7532 ; \mathrm{p}<0.02365$; Standard error of regression $\mathrm{s}=464.88 ; \mathrm{N}=90$

\begin{tabular}{lcccccc}
\cline { 2 - 6 } & $\mathrm{b}^{*}$ & $\begin{array}{c}\text { Standard error } \\
\text { from } b^{*}\end{array}$ & $\mathrm{~b}$ & $\begin{array}{c}\text { Standard error } \\
\text { from } b\end{array}$ & $\mathrm{t}(261)$ & $\mathrm{p}$ \\
\hline Const. & & & 3563.697 & 302.7525 & 11.77099 & 0.000000 \\
\hline
\end{tabular}




\begin{tabular}{lcccccc}
\hline Type of building & 0.357496 & 0.105270 & 346.769 & 102.1113 & 3.39599 & 0.001047 \\
\hline Area of apartment & -0.137792 & 0.100948 & -5.470 & 4.0076 & -1.36498 & 0.175903 \\
\hline Acoustic zone & 0.041251 & 0.101977 & 41.224 & 101.9110 & 0.40451 & 0.686866 \\
\hline f0 & -0.032456 & 0.232310 & -31.521 & 225.6193 & -0.13971 & 0.889224 \\
\hline f1 & 0.032456 & 0.232310 & 31.521 & 225.6193 & 0.13971 & 0.889224 \\
\hline
\end{tabular}

Summary of dorsal regressions for dependent variables: Unit price

Variable $\mathrm{I}=0.10000 ; \mathrm{R}=0.34279818 ; \mathrm{R}$-squared $=0.11751059$;

Adjusted R-squared $=0.10748230 ; \mathrm{F}(1.88)=11.718 ; \mathrm{p}<0.00094 ;$ Standard error of regression $\mathrm{s}=460.30 ; \mathrm{N}=90$

\begin{tabular}{|c|c|c|c|c|c|c|}
\hline & $b^{*}$ & $\begin{array}{c}\text { Standard error } \\
\text { from } b^{*}\end{array}$ & $\mathrm{~b}$ & $\begin{array}{c}\text { Standard error } \\
\text { from b }\end{array}$ & $t(261)$ & $\mathrm{p}$ \\
\hline Const. & & & 3320.805 & 65.66797 & 50.56963 & 0.000000 \\
\hline Type of building & 0,326845 & 0.095481 & 317.038 & 92.61618 & 3.42314 & 0.000942 \\
\hline \multirow[t]{2}{*}{ Variable } & \multicolumn{6}{|c|}{$\begin{array}{l}\text { Summary of dependant variable regression: Unit price } \\
\mathrm{R}=0.35952976 ; \mathrm{R}-\text { squared }=0.12926165 ; \\
\text { djusted } \mathrm{R} \text {-squared }=0.11936689 ; \mathrm{F}(1.88)=13.064 ; \mathrm{p}<0.00050 ; \\
\text { Standard error of regression } \mathrm{s}=457.23 ; \mathrm{N}=90\end{array}$} \\
\hline & $b^{*}$ & $\begin{array}{c}\text { Standard error } \\
\text { from } b^{*}\end{array}$ & b & $\begin{array}{l}\text { Standard error } \\
\text { from } b\end{array}$ & $t(261)$ & $\mathrm{p}$ \\
\hline Const. & & & 3305.657 & 66.69377 & 49.56471 & 0.000000 \\
\hline Type of building & 0.359530 & 0.099472 & 348.742 & 96.48778 & 3.61437 & 0.000501 \\
\hline
\end{tabular}

Source: own study.

The parameters of the regression function showed statistical significance (at the level of $p<0.01$ ). Based on the constructed model, it can be concluded that the prices of apartments in this area were influenced by the type of building (stimulant) - a flat being located in a low building resulted in an increase in unit price by $0.36 \mathrm{PLN} / \mathrm{m}^{2} \mathrm{UA}$ on average. R-squared indicator was 0.12926165 . This means that the constructed model explained less than $13 \%$ of changes of the dependent variable. The value of the adjusted R-squared indicator (accounting for the number of independent variables in the model) equalled 0.11936689 and did not deviate significantly from the general coefficient.

\section{Conclusions}

In this article, an attempt to verify the following hypothesis: for residential premises located at Kujawska St., noise is feature that reduces their price. When analyzing the spatial layout of the residential complex, it was found that the majority of noise sensitive objects are located in the QUIET ZONE. This means that space is well-planned and in line with the principles of sustainability. This minimizes spatial conflicts that occur as they interface with areas serving various functions (here: residential and transportation). Following the analyses above, it was found the average price of $1 \mathrm{~m}^{2}$ of housing exposed to noise nuisance in the NOISE ZONE, lying in the vicinity of the DK25 national road - Kujawska St., is $1.9 \%$ lower than the price of apartments in the QUIET ZONE; however, the difference was not found to be statistically significant. However based on the results of linear regression for Kujawska St., it can be concluded that there is a relationship between the price of an apartment and the type of building (low, high). The presented case studies do not provide a basis for the positive verification of the study hypothesis that noise generated by the transport route influences a reduction in the prices of flats in its neighborhood.

In the present research, which is focused on highly urbanized housing estate, the differences in prices are not statistically significant, so it is reasonable to assume that buyers place other advantages of the selected housing complex above road traffic noise, and that they are inclined to accept the nuisance associated with such noise. This is confirmed by the results of linear regression analysis. This shows that, with respect to the housing market for the analyzed housing estate, noise is not yet a feature that unambiguously determines lower prices of apartments located near transportation routes. The above can also be the consequence of so-called "environmental pseudo-adaptation". In a space where transportation innovations do not appear for the market participants (concerning the expansion of an existing road or the introduction of a new solution with a much higher traffic density, e.g. a ring road), 
the existing transportation system is merely a way to access the property. Residing in a space that has been unchanged for years, they become accustomed to various nuisances, which, after some time, they cease to notice, and subjectively perceive the space in a more positive light than its actual, objective image (e.g. acoustic measurement or SNM data). It is therefore possible that, for housing districts located near existing roads, the impact of noise on prices is not significant; this conclusion requires further research and analyses.

As shown by the literature review and our own research, the research problem in question is important, both from a scientific and cognitive point of view. The statistically insignificant difference in housing prices does not necessarily mean that it is insignificant in practice, and vice versa. This is because the statistical reflection does not take into account the subjective perceptions of buyers regarding traffic noise nuisance, responding to the tested research hypothesis only in an objective way. Therefore, any analyses of the problem in question should refer to local markets, which will take into account the subjective preferences of buyers, their sensitivity, the wealth of the society and the level of the socio-economic development of the region. The above requires further investigation in additional research. The results of this type of analysis are helpful in decision-making regarding investments for all real estate market participants as well as urban planners, who plan space with regard to spatial order.

This research was conducted using a strategic noise map. This tool is currently considered to be the main tool for tackling the problem of noise in all European Union countries. The SNM process involves a detailed diagnosis of urban space, taking into account many factors, environmental and non-environmental, a part of which expressed in the detailed location affects the value of the property. The final product of the SNM system is an immission map which records the acoustic situation in the city. The process of creating it usually lasts from a few to several months, whilst the validity of the SNM under EU law is five years. The availability of this source and its legally validated status provide a basis for its implementation for purposes of real estate management. We must, however, remember that SNMs do not account for the variance of noise over time. An immission map presents the impact of noise at a given moment in time, in relation to the characteristics of the source at the time of its preparation. Therefore, for a several-year study period, it may not reveal a complete picture of the acoustic situation in a city.

\section{References}

Aiyin, W., \& Yanmei, X. (2018) Multiple Linear Regression Analysis of Real Estate Price. International Conference on Robots \& Intelligent System (ICRIS), 564-568. https://doi.org/10.1109/ICRIS.2018.00145

Anselin, L., \& Rey, S. (1991). Properties of Tests for Spatial Dependence in Linear Regression Models. Geographical Analysis, 23(2), 112-131. https://doi.org/10.1111/j.1538-4632.1991.tb00228.x

Blanco, J. C., \& Flindell, I. (2011). Property prices in urban areas affected by road traffic noise. Applied Acoustics, 72(4), 133-141. https://doi.org/10.1016/j.apacoust.2010.11.004

Brandt, S., \& Maennig, W. (2011). Road noise exposure and residential property prices: Evidence from Hamburg. Transportation Research Part D: Transport and Environ, 16(1), 23-30. https://doi.org/10.1016/j.trd.2010.07.008

Cellmer, R. (2011). Spatial Analysis of the Effect of Noise on the Prices and Value of Residential Real Estates. Geomatics and Environmental Engineering. 5(4), 13-28.

Del Giudice, V., De Paola, P., Manganelli, B., \& Forte, F. (2017). The Monetary Valuation of Environmental Externalities through the Analysis of Real Estate Prices. Sustainability, 9(2), 229. https://doi.org/10.3390/su9020229

EEA. 2014. European Environment Agency, EEA Report No. 10/2014, Noise in Europe 2014. Available online: https://www.eea.europa.eu/publications/noise-in-europe-2014/file (accessed on 14 April 2019).

END 2002. Directive 2002/49/EC of the European Parliament and of the Council of 25 June 2002 relating to the assessment and management of environmental noise - Official Journal of the European Communities L 189 of 18 July 2002 (accessed on 14 April 2019).

Gnat, S., \& Bas, M. (2014). Badanie wpływu immisji hałasu komunikacyjnego na ceny lokali mieszkalnych (Study of impact of communication noise immission on the prices of residential premises). In S. Źróbek (Ed.), Analiza rynku i zarządzanie nieruchomościami. TNN Olsztyn, 73-85. 
Gnat, S., \& Bas, M. (2017). Próba wykorzystania zjawiska hałasu komunikacyjnego do oceny atrakcyjności lokalizacji (An attempt to use the phenomenon of communication noise to assess the attractiveness of a location). Rzeczoznawca Majątkowy, 1, 18-23.

Hozer, J. (Ed.). (2001). Nieruchomości, Przedsiębiorstwa, Wyceny, Analizy (Real Estate, Enterprises, Valuations, Analyzes). Uniwersytet Szczeciński.

King, E. A., \& Murphy, E. (2016). Environmental noise-'Forgotten'or 'Ignored'pollutant? Applied Acoustics, 112, 211-215. https:// doi.org/10.1016/j.apacoust.2016.05.023

Krajewska, M., \& Szopińska, K. (2012). Noise Level in Relation to Real Estate Prices in Selected Settlements in Poland, Proceedings of the FIG Working Week 2012, Rome, Italy, 6-10 May 2012. Available online: TS06H_krajewska_szopinska_5538.pdf

Lewis, C. A., Buffington, J. L., Vadali, S. R., \& Goodwin, R. E. (1997). Land Value and Land Use Effects of Elevated, Depressed, and At-Grade Level Freeways in Texas, (No. FHWA/TX-98/1327-2). July 1997. Available online: https://static.tti.tamu.edu/tti.tamu.edu/ documents/1327-2.pdf (accessed on 14 April 2019).

Levkovich, O., Rouwendal, J., \& van Marwijk, R. (2016). The effects of highway development on housing prices. Transportation, 43(2), 379-405. https://doi.org/10.1007/s11116-015-9580-7

Murphy, E., \& Douglas, O. (2018). Population exposure to road traffic noise: Experimental results from varying exposure estimation approaches. Transportation Research Part D, Transport and Environment, 58, 70-79. https:// doi.org/10.1016/j.trd.2017.11.006

Noga, K., Balawejder, M., \& Nosek, G. (2018). Ways of Acquiring Land Property for the Construction of Province Roads. Real Estate Management and Valuation, 26(1), 108-121. https://doi.org/10.2478/remav-2018-0009

Obwieszczenie Ministra Środowiska z dnia 15 października 2013 r. w sprawie ogłoszenia jednolitego tekstu rozporządzenia Ministra Środowiska w sprawie dopuszczalnych poziomów hałasu w środowisku, Tekst jedn. Dz. U. Nr 0/2014, poz. 112. (Regulation of 2013. Announcement by the Minister of Environment of 15 October 2013 on the publication of a single text of the Regulation of the Minister of the Environment on permissible noise level in the environment, Journal of Laws, 2014, No. 0, item 112).

Olbińska, K. (2015). The influence of real estate on its surroundings based on the example of the Manufaktura complex in Lodz. Real Estate Management and Valuation, 22(4), 5-16. https://doi.org/10.2478/remav-2014-0032

Palmquist, R. (1979) Impact of Highway Improvements on Property Values in Washington (No. Final Rpt.), March 1979. Available online: http://www.wsdot.wa.gov/research/reports/ fullreports/037.1.pdf (accessed on 10 April 2019).

Rącka, I. (2017). Jakość informacji na rynku nieruchomości w Polsce (The Quality of Information on the Real Estate Market in Poland). Problemy Jakości, 49(4), 19-25. https://doi.org/10.15199/48.2017.4.3

Radziszewska, W., \& Jaroszewicz, J. (2013). Analysis of Changes in Prices of Land in the Vicinity of National Roads. Real Estate Management and Valuation, 21(1), 77-87. https://doi.org/10.2478/remav-2013-0010

Rich, J. H., \& Nielsen, O. A. (2004). Assessment of traffic noise impacts. International Journal of Environmental Studies, 61(1), 19-29. https://doi.org/10.1080/ 0020723032000113790

SNM. (2017). Strategic Noise Map of Bydgoszcz City. Available online: http://mapy.bydgoszcz.pl/ (accessed on 10 June 2017).

Szczepańska, A., Senetra, A., \& Wasilewicz, M. (2014). Traffic Noise as a Factor Influencing Apartment Prices in Large Cities. Real Estate Management and Valuation, 22(3), 37-44. https://doi.org/10.2478/remav-2014-0025

Szczepańska, A., Senetra, A., \& Wasilewicz-Pszczółkowska, M. (2015). The effect of road traffic noise on the prices of residential property - A case study of the polish city of Olsztyn. Transportation Research Part D, Transport and Environment, 36, 167-177. https://doi.org/10.1016/j.trd.2015.02.011

Szopińska, K. (2017). Creation of Theoretical road traffic noise model with the help of GIS. Proceedings of the "Environmental Engineering" 10th International Conference Vilnius Gediminas Technical University, Vilnius, Lithuania, 27-28 April, 1-8, https://doi.org/10.3846/enviro.2017.122 
Szopińska, K. (2018). Identyfikacja hałasu drogowego a badania rynku nieruchomości mieszkaniowych (Identification of road traffic noise and research of residential real estate market), Problemy Rynku Nieruchomości. Biuletyn Stowarzyszenia Rzeczoznawców Majątkowych Województwa Wielkopolskiego, 1(49), 108-115.

Szopińska, K., \& Krajewska, M. (2016). Methods of Assessing Noise Nuisance of Real Estate Surroundings. Real Estate Management and Valuation, 24(1), 19-30. https://doi.org/10.1515/remav2016-0002

Ustawa z dnia 27 kwietnia 2001 r. Prawo Ochrony Środowiska, Tekst jedn. Dz. U. Nr 0/2013, poz. 1232, z późn. zm. (Act of 27 April 2001 Environmental Protection Law, Journal of Laws, 2013, No. 0, item 1232 , as amended).

Wadud, Z. (2013). Using meta-regression to determine Noise Depreciation Indices for Asian airports. Asian Geographer, 30(2), 127-141. https://doi.org/10.1080/10225706.2013.778580

Wilhelmsson, M. (2000). The impact of traffic noise on the values of single-family houses. Journal of Environmental Planning Management, https://doi.org/10.1080/09640560020001692. 